J. Clin. Chem. Clin. Biochem.

Vol. 14, 1976, pp. 401-406

\title{
An Immunological Turbidimetric Method for Serum Transferrin Determination
}

\author{
By H.J. H. Kreutzer \\ with the technical assistance of Miss Anneke Koning
}

Clinical chemical Laboratory Groot Ziekengasthuis 's-Hertogenbosch The Netherlands

(Received January 22/April 27, 1976)

Summary: The described method for the turbidimetric determination of serum transferrin concentration has the following features: the ionic strength of the medium is very low, the antiserum used is purified by the manufacturer, $25 \mu \mathrm{l}$ antiserum per determination is sufficient, excess antibody or antigen has no influence.

We studied the relation between transferrin concentration and total iron binding capacity for human normal and variant transferrins. Furthermore, our results are compared with the radial immunodiffusion technique.

\section{Immunologische turbidimetrische Methonde zur Bestimmung von Transferrin im Serum}

Zusammenfassung: Die für die Transferrinbestimmung im Serum beschriebene turbidimetrische Methode hat folgende Charakteristika: Die Ionenstärke des Mediums ist sehr gering. Das benutzte Antiserum ist vom Hersteller gereinigt, $25 \mu \mathrm{l}$ Antiserum pro Bestimmung sind ausreichend, es gibt keinen Einfluß von Antikörper- oder Antigenüberschuß.

Wir untersuchten die Beziehung zwischen Transferrinkonzentration und Gesamt-Eisenbindungskapazität für normales Transferrin und -varianten des Menschen. Die Ergebnisse der turbidimetrischen Methode wurden mit durch radiale Immundiffusion erhaltenen verglichen.

\section{Introduction}

The first technique for the specific determination of proteins in the clinical laboratory was the immunoprecipitation technique with a turbidimetric measurement of the amount of precipitate formed $(1,2)$. This technique is relatively simple and requires no special equipment. The drawbacks are the high blank value, the large amount of antiserum and the small working range due to the decrease in absorbance in the zone of antigen excess.

We have studied some of the mechanisms involved in the complex formation and developed a method for serum transferrin determination with a low blank value and only $2 \overline{5} \mu \mathrm{l}$ antiserum for one determination. The zone of antigen excess starts at concentrations of about $20 \mathrm{~g} / \mathrm{l}$ transferrin.

\section{Materials and Mèthods}

\section{Reagents}

Diluent: dilute $200 \mathrm{mmol} / 1$ tris buffer $\mathrm{pH} 7.5100$ times with distilled water. (Demineralised water may be used as well, but we observed a varying turbidity in the serum dilutions, when the conductivity of water was more than $5 \mu \mathrm{S}$ ).
Antisera: antitransferrin antisera were from Dakopatts Copenhagen, Behring Werke and the Red Cross Blood Transfusion Laboratory, Amsterdam. The Dakopatts antisera are purified by the manufacturer by salting out and ion-exchange chromatography.

Standard: standard human serum of Behring Werke (ORDT 03).

Instrument

A Vitatron UFD photometer with mercury lamp and microcuvet $(100 \mu \mathrm{l})$ was used for all measurements. The cuvet was rinsed with about $150 \mu \mathrm{l}$ sample and filled with the remaining sample for the measurement. We isolated the mercury line of $365 \mathrm{~nm}$ with an interference filter. The Eppendorf photometer $1101 \mathrm{M}$ with cuvet 4040 can also be used.

\section{Transferrin determination}

Dilute antitransferrin Dakopatts with diluent 10 times (I); dilute $20 \mu \mathrm{l}$ serum with $3.5 \mathrm{ml}$ diluent (II); $\mathrm{mix}$ in glass agglutination tubes $100 \mu \mathrm{lI}$ with $250 \mu \mathrm{I}$; incubate 30 minutes at room temperature, and read the absorbance of the mixture at $365 \mathrm{~nm}$ in a microcuvet against the antiserum blank $(100 \mu \mathrm{l}$ diluent and $250 \mu \mid \mathrm{I}$ ): $A_{\text {determination; read the absorbance of }}$

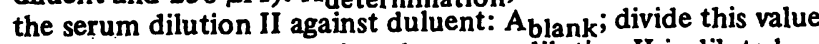
by 3.5 (in the determination the serum dilution II is diluted 3.5 times with solution I) and substract this from the absorbance of the incubated mixture:

$A=A_{\text {determination }}-\frac{A_{\text {blank }}}{3.5}$. 
Determine the concentration from a calibration curve constructed with various dilutions of the standard serum.

\section{Standard curve}

Make the following dilutions using the same pipets as for the transferrin determination:

$20 \mu \mathrm{l}$ standard serum $+4 \times 3.5 \mathrm{ml}$ diluent

$2 \times 20 \mu \mathrm{l}$ standard serum $+3 \times 3.5 \mathrm{ml}$ diluent

$20 \mu \mathrm{l}$ standard serum $+\quad 3.5 \mathrm{ml}$ diluent

$3 \times 20 \mu$ standard serum $+2 \times 3.5 \mathrm{ml}$ diluent.

\section{Other methods}

Total iron binding capacity was determined following Caraway (3) with ferrozine as chromogen (4).

The radial immunodiffusion tests were done with M-Partigen plates of Behring Werke.

\section{Experiments}

\section{Salt concentration}

In the literature various diluents are used for the dilution of serum and antiserum: $70 \mathrm{mmol} / \mathrm{l}$ phosphate buffer (1), $1100 \mathrm{mmol} / \mathrm{l}$ sodium chloride (2) and $150 \mathrm{mmol} / \mathrm{l}$ sodium chloride (5). Figure 1 shows the effects of these diluents and of distilled water. By decreasing the ionic strength a very striking increase in sensitivity is obtained. With higher salt concentrations the lower transferrin concentrations give no turbidity at all. With three dilutions of tris buffer $\mathrm{pH} 7.5(200-20-2 \mathrm{mmol} / \mathrm{l})$ as diluent the same influence of salt concentration is seen. We found that the reproducibility of turbidity was better with $2 \mathrm{mmol} / \mathrm{l}$ tris than with distilled water. Throughout this study we therefore used $2 \mathrm{mmol} / 1$ tris buffer as diluent.

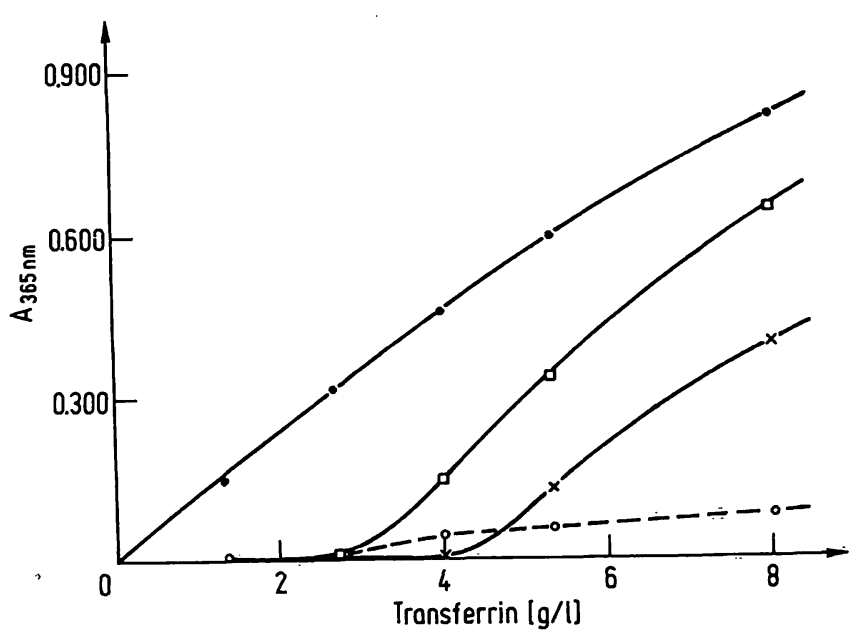

Fig. 1. Calibration curves for various diluents:

$\bullet-\bullet$ distilled water

$n \longrightarrow 150 \mathrm{mmol} / \mathrm{l}$ sodium chloride

$x-\times 70 \mathrm{mmol} / \mathrm{l}$ phosphate buffer, $\mathrm{pH} 7.5$

$\circ-01100 \mathrm{mmol} / \mathrm{l}$ sodium chloride. Dakopatts antiserum was diluted $1+3$.

\section{Antiserum}

In figure 2 we compare three antisera. The titer of the antisera of Behring Werke and Dakopatts was higher than that of the Red Cross. The antiserum blank of the Dakopatts antiserum had an absorbance of about 0.060 , that of Behring Werke about 0:200. Therefore Dakopatts antitransferrin was used in our procedure.

The amount of antiserum was determined by making dilutions of the antiserum: figure 3. Normal-transferrin values should give absorbance values of about 0.300 . The dilution of the antiserum therefore was $1+10$.

The zone of antigen excess starts at concentrations of about $20 \mathrm{~g} / \mathrm{l}$ transferrin. A typical standard curve is shown in figure 4.

Using undiluted antisera practically linear calibration curves can be obtained. The high cost of antisera and the high antiserum blank are serious drawbacks for this variation.

\section{Temperature}

We found only minor variations between calibration curves produced at $4^{\circ} \mathrm{C}, 25^{\circ} \mathrm{C}$ and $37^{\circ} \mathrm{C}$. Room temperature ist most convenient.

\section{Incubation time}

After 30-45-60-90 minutes incubation identical tubidities were measured. After 15 minutes the values

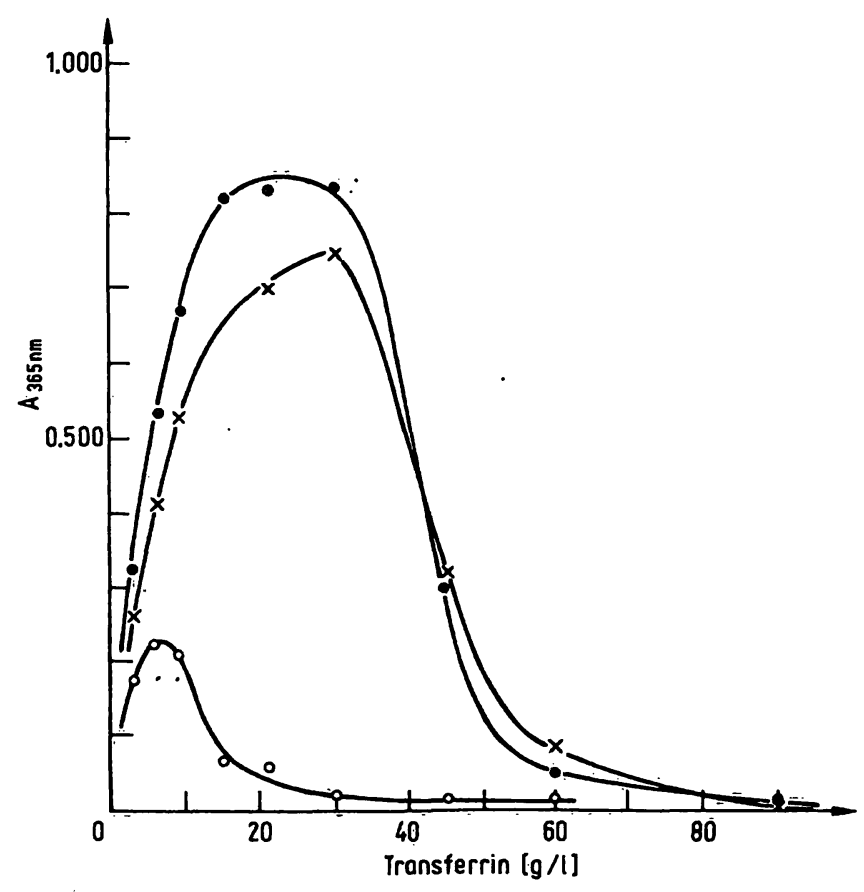

Fig. 2. Extended calibration curves with three different àntisera, diluted $1+7$ with $2 \mathrm{mmol} / \mathrm{l}$ tris buffer.

- - Dakopatts

0 - 0 Red Cross, Amsterdam

$x-x$ Behring Werke. 


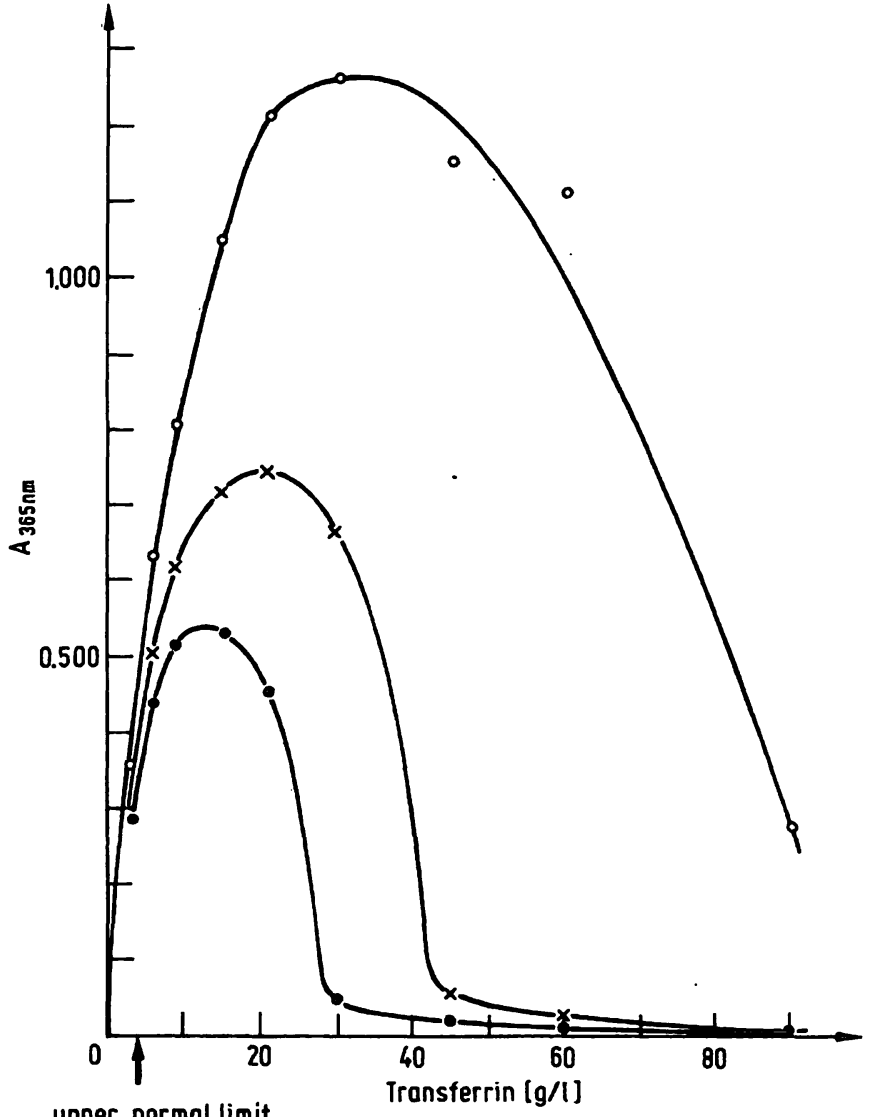

upper normal limit

Fig. 3. Extended calibration curves with Dakopatts antiserum diluted with $2 \mathrm{mmol} / 1$ tris buffer.

$0-0$ dilution $1+3$

$x-x$ dilution $1+7$

$\bullet$ dilution $1+15$.

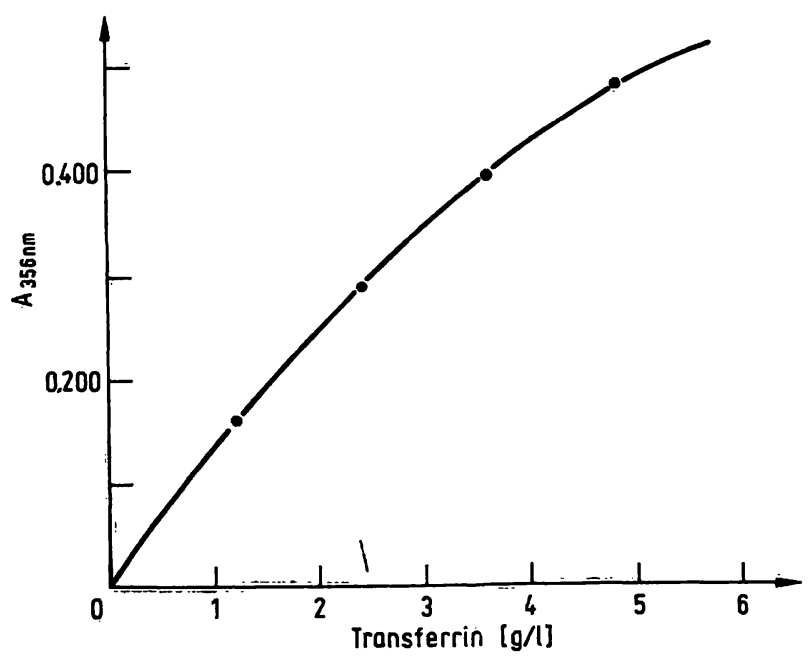

Fig. 4. Standard curve with Behring Werke standard human serum as described under "standard curve".

were about $10 \%$ lower. Liżana \& Hellsing (6) describe the accelerating and enhancing action of polyethyleneglycol on automated nephelometric protein assays. We could not find any effect of polyethyleneglycol in our procedure. The incubation time was set at 30 minutes and is not critical.
Effect of lipoproteins, bilirubin and hemoglobin on the serum blank

In table 1 the effect of bilirubin and hemoglobin on the serum blank values is illustrated. Bilirubin does not influence the blank; hemoglobin causes high blank values only when marked hemolysis has occurred.

In table 2 the blank values of sera with high concentrations of $\beta-$, pre- $\beta$-lipoproteins and chylomicrons are presented. Only chylomicrons elevate the blank values.

Normally serum blanks are very low: $A_{\text {blank }}>0.030$.

Tab. 1. Influence of the addition of bilirubin and hemoglobin on the serum blank absorbance $\frac{A_{\text {blank }}}{3.5}$.

\begin{tabular}{llll}
\hline $\begin{array}{l}\text { bilirubin added } \\
\mu \mathrm{mol} / 1\end{array}$ & $\begin{array}{l}\text { serum blank } \\
\text { absorbance }\end{array}$ & $\begin{array}{l}\text { hemoglobin added } \\
\mu \mathrm{mol} / 1\end{array}$ & $\begin{array}{l}\text { serum blank } \\
\text { absorbance }\end{array}$ \\
\hline 0 & 0.011 & 0 & 0.004 \\
100 & 0.013 & 5 & 0.015 \\
200 & 0.011 & 10 & 0.026 \\
500 & 0.011 & 20 & 0.048 \\
\hline
\end{tabular}

Tab. 2. Serum blank absorbance $\frac{A_{\text {blank }}}{3.5}$ of sera with elevated concentrations of lipoproteins.

\begin{tabular}{|c|c|c|c|}
\hline $\begin{array}{l}\text { electrophoresis } \\
\text { lipoproteins elevated }\end{array}$ & $\begin{array}{l}\text { cholesterol } \\
\mathrm{mmol} / 1\end{array}$ & $\begin{array}{l}\text { triglycerides } \\
\mathrm{mmol} / \mathrm{l}\end{array}$ & $\begin{array}{l}\text { serum blank } \\
\text { absorbance }\end{array}$ \\
\hline$\beta$-lipoproteins & 11.0 & 1.6 & 0.011 \\
\hline$\beta$-lipoproteins & 10.1 & 3.9 & 0.007 \\
\hline$\beta$-lipoproteins & 10.0 & 2.3 & 0.003 \\
\hline$\beta$-lipoproteins & 13.4 & 3.3 & 0.006 \\
\hline$\beta$ - and pre $\beta$-lipoproteins & 9.7 & 9.0 & 0.014 \\
\hline pre $\beta$-lipoproteins & 6.7 & 7.6 & 0.009 \\
\hline preß-lipoproteins & 7.5 & 4.8 & 0.006 \\
\hline chylomicrons & 4.9 & 3.0 & 0.022 \\
\hline chylomicrons & 5.4 & 9.4 & 0.055 \\
\hline chylomicrons & 5.1 & 9.4 & 0.071 \\
\hline
\end{tabular}

Țotal iron binding capacity and transferrin concentration

We compared the total iron binding capacity and the transferrin concentration of 57 sera of hospital patients: figure 5a. A good correlation was found between these parameters. In figure $5 \mathrm{~b}$ the same comparison is made for 13 sera of persons having a genetic variant of transferrin. Some of the electrophoretic patterns of these variants are shown in figure 6 . The transferrin values are possibly somewhat higher in relation to the iron binding capacity.

\section{Correlation}

Transferrin was measured immuno-chemically in 46 patient-sera by the radial immunodiffusion technique (determinations were done by Miss Bernsen of Hoechst- 


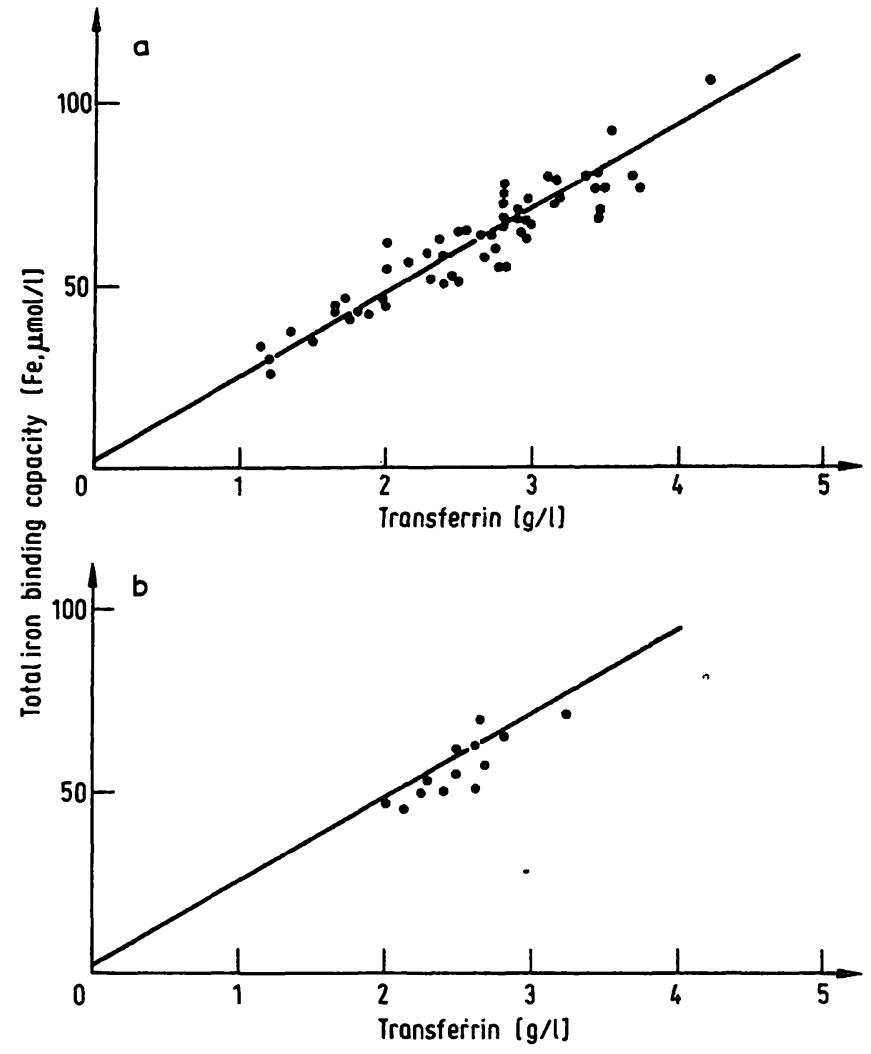

Fig. 5 a. Relation between total iron binding capacity and transferrin concentration as measured with the described method. Correlation was calculated from the data of 57 hospital patients. $y=2.2+23.0 x ; r=0.93$.

Fig. 5 b. Relation between total iron binding capacity and transferrin concentration for transferrin variants. The correlation line of figure $5 \mathrm{a}$ is drawn for comparison.

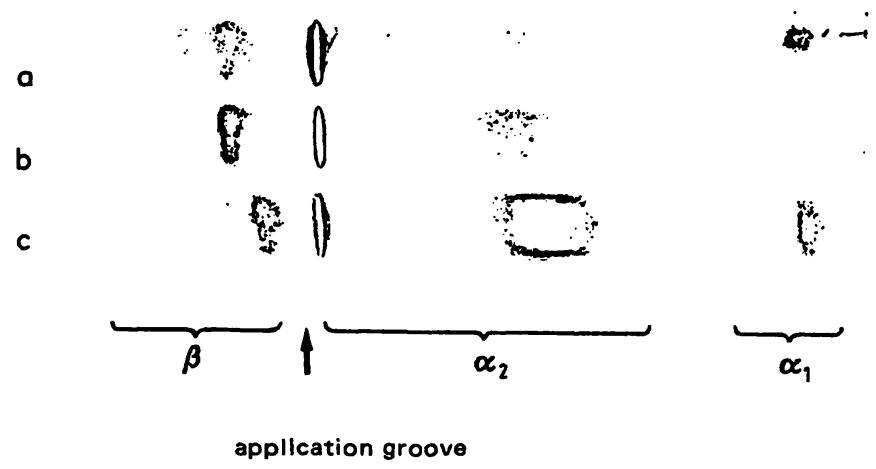

Fig. 6. Agar electrophoretic patterns of two sera with variant transferrins.

a. transferrin B-C

b. transferrin $C$

c. transferrin C-D

Normal transferrin is transferrin $C$.

Holland) and the proposed method. Both methods were standardised with the same lot of standard human serum. The values showed a good correlation as is seen in figure 7. In the sub-normal region the turbidimetric method gives higher values. In the normal and high region the results are nearly the same for both methods.

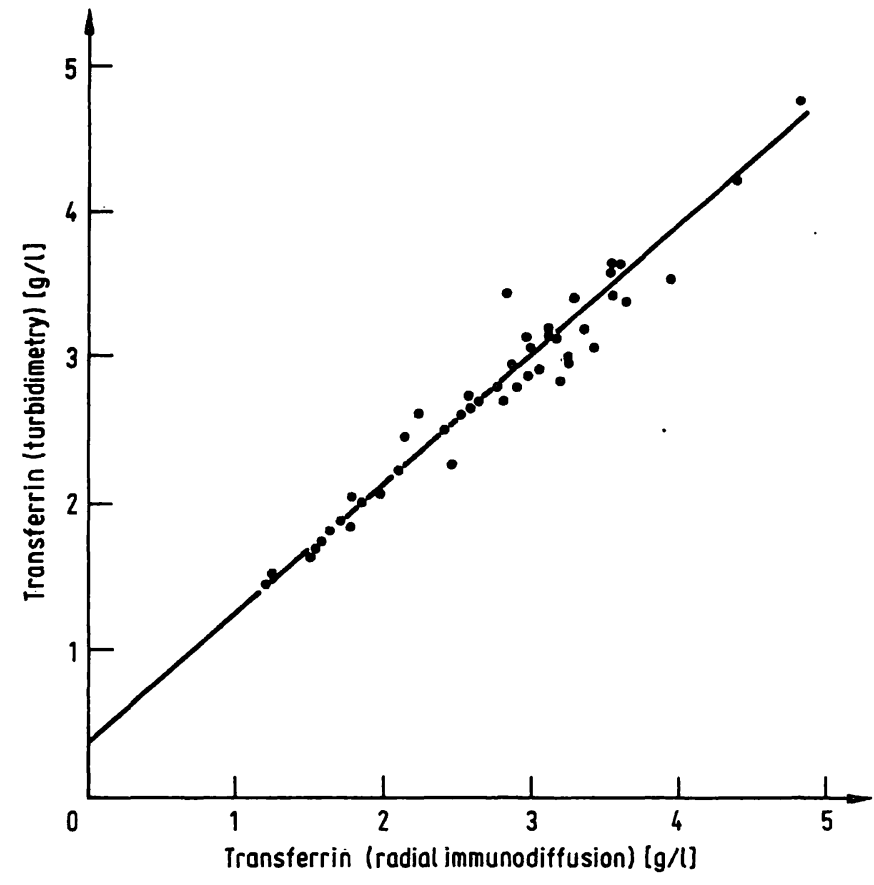

Fig. 7. Relation between transferrin measured by turbidimetry and radial immunodiffusion. $n=46 ; y=0.88 x+0.38 ; r=0.97$.

\section{Reproducibility}

The coefficient of variation calculated from the difference between duplicates is about $3 \%$, the day to day variation is about $5 \%$.

\section{Discussion}

The nephelometric determination of proteins has received new attention. Automated systems have been developed and the conditions of antigen-antibody reactions have been studied $(7,8,9)$. These systems demand high investments: for the measurement of invisible turbidity a sensitive nephelometer is needed.

In our determination we reduced the end volume of the reaction mixture in order to reduce the amount of antiserum although we still meașure a visible turbidity at high antiserum concentrations. The sensitivity of the nephelometer therefore is not required as the turbidity can be measured reproducibly in a photometer at a wavelength of $400 \mathrm{~nm}$ or less. We used a photometer with a mercury lamp. The high intensity of the $365 \mathrm{~nm}$ line ensures enough light to pass through the small slit of the microcuvet.

In, our test a visible precipitate must be formed, even at low concentrations. We found that a very dilute salt solution enhances the formation of this precipitate. Possibly the poor solubility of immunoglobulins in this medium is responsible for this effect. 
In the clinical laboratory transferrin is determined mainly for the investigation of iron metabolism. The determination of total iron binding capacity therefore is a physiological approach. However van der Heul et al. (10) showed that the saturation of transferrin in vitro with a large amount of iron and elimination of the unbound iron with magnesium-carbonate is not specific. Some other proteins were shown to bind iron under these conditions. The authors concluded, that an immunological method for transferrin is superior. In our material (fig. 5a) we find an intercept with the $y$-axis of about $2 \mu \mathrm{mol} / 1$ iron binding capacity. This can be caused by non-specific binding of iron by other proteins.

$1 \mathrm{~g}$ of transferrin corresponds to $23.0 \mu \mathrm{mol}$ iron binding capacity. This is in agreement with values found by Tsung et al. (11) for pure transferrin as calculated from a radio-isotopic method and two colorimetric procedures: 23.3, 23.1 and $22.6 \mu \mathrm{mol}$. As transferrin has a molecular mass of 76,000 (12) and two binding sites per molecule, $1 \mathrm{~g}$ of transferrin must

correspond to $\frac{1,000,000}{76,000} \times 2=26.3 \mu \mathrm{mol}$ iron binding capacity. The difference between calculated and found conversion factors can be caused by an incomplete removal of iron from transferrin as demonstrated by Olsen \& Hamlin (13).

The correlation with the radial immunodiffusion technique is rather good (fig. 7). We cannot explain the difference between the methods at lower concentrations.

Possibly the turbidimetric one has a lower specificity in this region. Differences in antiserum may also cause the effect. Schmidt et al. (14) found similar differences between the automated nephelometric and radial immunodiffusion methods, using the same antiserum for both methods.

Standardisation of all immunological methods is difficult. Purification of a protein may cause denaturation of some antigenic determinants of the molecule. Therefore we preferred standardisation with a stabilised human serum (that is calibrated by the manufacturer by measuring against purified transferrin in a radial immunodiffusion technique).

For reference values we determined the transferrin content of sera of 54 men and 30 women who were apparently healthy. We also calculated the corresponding iron binding capacity. The values for women tended to be somewhât lower (fig. 8).

The combined reference values are:

transferrin $2.3-3.8 \mathrm{~g} / \mathrm{l}$

iron binding capacity $60-100 \mu \mathrm{mol} / \mathrm{l}$.

In our population $1.9 \%$ has a variant transferrin of one of the types shown in figure 6 . We investigated the

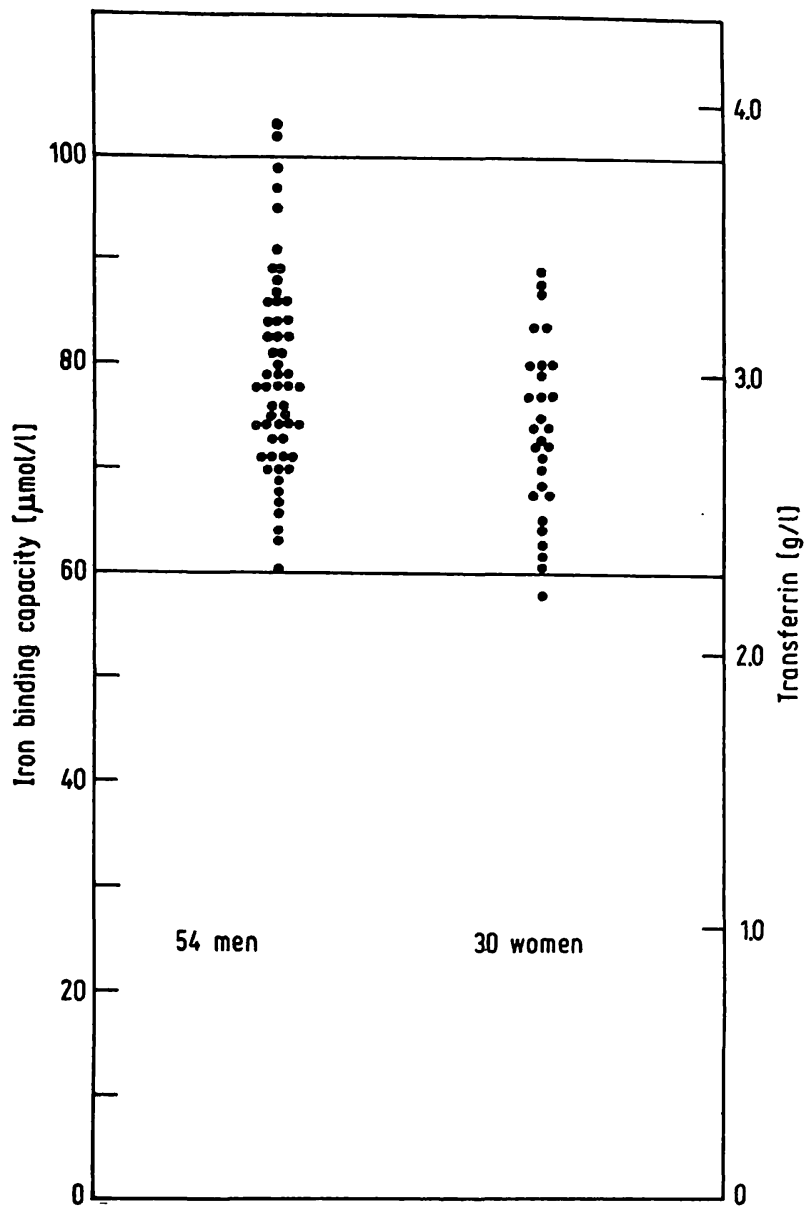

Fig. 8. Transferrin and calculated iron binding capacity values for normal healthy men and women.

relation of the iron binding capacity and the transferrin concentration as measured by our method to see if there are striking differences in the determination of transferrin caused by differences in the antigen molecule.

Turnbull et al. (15) found no differences in the iron binding capacity between normal and several variant transferrins. Difficulties could be encountered if the antiserum contains antibodies with lower or higher aftinity to the variant molecules. Our antiserum obviously does not discriminate seriously between normal and variant transferrin.

The method proposed can be used for all proteins provided that good antisera are available. Methods for haptoglobin and the immunoglobulins are under investigation.

\section{Acknowledgement}

I am greatly indebted to my father Dr. H. H. Kreutzer and Miss Yvette Förch who carried out the method in the clinical chemical laboratory of the Rooms Katholieke Ziekenverpleging, Hilversum and discussed the various problems. 


\section{References}

1. Schultze, H. E. \& Schwick, G. (1959), Clin. Chim. Acta 4, $15-25$.

2. Goodman, M., Newman, H. S. and Ramsay, D. S. (1958), J. Lab. Clin. Med. 51, 814-823.

3. Caraway, W. T. (1963), Clin. Chem. 9, 188-199.

4. Persijn, J. P., van der Slik, W. \& Riethorst, A. (1971), Clin. Chim. Acta 35, 91-98.

5. Ritchie, R. F. (1967), J. Lab. Clin. Med. 70, 512-517.

6. Lizana, J. \& Hellsing, K. (1974), Clin. Chem. 20, 1181-1186.

7. Killingsworth, L. M. \& Savory, J. (1972), Clin. Chem. 18, $335-339$.

8. Killingsworth, L. M. \& Savory, J. (1973), Clin. Chem. 19, 403-407.

9. Killingsworth, L. M., Buffone, G. J., Sonawane, M. B. \& Lunsford, G. C. (1974), Clin. Chem. 20, 1548-1552.
10. van der Heul, C., van Eyk, H. G., Wiltink, W. F. \& Leynse, B. (1971), Clin. Chim. Acta 38, 347-353.

11. Tsung, S. H., Rosenthal, W. A. \& Milewski, K. A. (1975), Clin. Chem. 21, 1063-1066.

12. Palmour, R. M. \& Sutton, H. E. (1971), Biochemistry 10, 4026-4032.

13. Olsen, A. D. \& Hamlin, W. B. (1969), Clin. Chem. 15 438-444

14. Schmidt, H., Ebeling, H. \& Kraft, D. (1975), this j. 13, 117-121.

15. Turnbull, A. \& Giblett, E. R. (1961), J. Lab. Clin. Med. 57, 450-459.
Dr. H. J. H. Kreutzer

Clin. Chem. Lab.

Groot Ziekengasthuis

Nieuwstraat 34

Den Bosch

The Netherlands 